
A. E. Lang
J. Duff
J. A. Saint-Cyr
L. Trepanier
R. E. Gross
W. Lombardi
E. Montgomery
W. Hutchinson

A. M. Lozano

\title{
Posteroventral medial pallidotomy in Parkinson's disease
}

\author{
Abstract There has been a resurgence \\ in the use of functional neurosurgery \\ for Parkinson's disease. An important \\ factor that has played a role in this \\ development is the recent understand- \\ ing of the functional anatomy of the \\ basal ganglia including a knowledge of \\ the changes in the activities of neurons \\ in the internal segment of the globus \\ pallidus (GPi) and the subthalamic \\ nucleus (STN) in Parkinson's disease \\ as well as the knowledge of the pres- \\ ence of segregated functional loops \\ within the basal ganglia which include \\ a sensory-motor loop that involves the \\ posteromedial globus pallidus rather \\ than the anterior GPi where earlier \\ pallidotomy lesions had been made. \\ Laitinen reintroduced the modern \\ posteroventral medial pallidotomy \\ (PVMP) in 1992. Since then it has \\ become clear that this treatment has \\ major effects on levodopa-induced
}

dyskinesias and, unlike Vim thalamotomy, improves bradykinesia and rigidity as well as tremor. In this report, we review a number of topics related to PVMP including the clinical results of pallidotomy available in the literature as well as an update of our own 2 year follow-up data, studies evaluating factors that might predict the subsequent response to pallidotomy, the neuropsychological effects of the procedure, results of imaging studies including the correlation of clinical effects with lesion location, the question of bilateral pallidotomy and pallidotomy combined with deep brain stimulation and finally whether PVMP is effective in other parkinsonian disorders.

Key words Parkinson's disease . Pallidotomy $\cdot$ Stereotactic surgery . Dyskinesias $\cdot$ Levodopa

\section{Introduction}

Considerable data is accumulating to support the efficacy of posteroventral medial pallidotomy in later stage Parkinson's disease. In this paper we will review our experience with pallidotomy at The University of Toronto as well as that described in the literature. A number of issues will be addressed including the clinical outcomes and duration of responses seen, whether any preoperative clinical factors predict outcome, the neuropsychological effects of pallidotomy, whether there is a relationship between the lesion loca- tion and clinical outcome, the results of functional imaging in patients having undergone pallidotomy, the role of bilateral pallidotomy and combined unilateral pallidotomy with contralateral pallidal stimulation and finally the role of pallidotomy in other parkinsonian disorders.

\section{Clinical outcomes}

Table 1 provides a summary of the available literature on pallidotomy. In general, these studies agree that pallidotomy 
Table 1 Summary of published results of posteroventral medial pallidotomy in Parkinson's disease *

\begin{tabular}{|c|c|c|c|c|c|c|c|c|c|}
\hline Author/yr & \# patients & Assessment & $\begin{array}{l}\text { Total } \\
\text { Scores; ADLs }\end{array}$ & Contra & Ipsi & Midline/axial & Dyskinesias & Major AEs & Comments \\
\hline $\begin{array}{l}\text { Svennilson et al. } \\
1960[57]\end{array}$ & $\begin{array}{l}81 ;<20 \% \text { post- } \\
\text { encephalitic; } \\
3 \text { bilateral } \\
\text { operations }\end{array}$ & $\begin{array}{l}\text { Quantitative } \\
\text { estimates of } \\
\text { gen. disability, } \\
\text { tremor, rigidity; } \\
\text { F/Us all cases } \\
>1 \mathrm{yr} \text {, some } \\
>5 \mathrm{yr}\end{array}$ & $\begin{array}{l}37 \% \text { from } \\
\text { dependent to } \\
\text { indep.; } 25 \% \\
\text { unemployed to } \\
\text { employed }\end{array}$ & $\begin{array}{l}\text { relief of rigidity } \\
\text { in } 79 \% \text {; tremor } \\
\text { in } 82 \% \text {; both in } \\
77 \%\end{array}$ & $\begin{array}{l}\text { improvement } \\
\text { largely confined } \\
\text { to contra. limbs }\end{array}$ & $\begin{array}{l}\text { gait and trunk } \\
\text { mobility also } \\
\text { improved }\end{array}$ & $\begin{array}{l}\text { pre-L-dopa; } \\
\text { painful muscle } \\
\text { spasms and } \\
\text { cramps (?dysto- } \\
\text { nia) abolished }\end{array}$ & $\begin{array}{l}\text { transient facial } \\
\text { or limb weak- } \\
\text { ness; bladder } \\
\text { dysfunction; } \\
\text { cognitive } \\
\text { decline }\end{array}$ & \\
\hline $\begin{array}{l}\text { Laitinen et al. } \\
1992 \text { [29] }\end{array}$ & $38 ; 4$ bilateral & $\begin{array}{l}\text { qualitative scor- } \\
\text { ing; writing and } \\
\text { drawing tasks } \\
\text { F/U 2-71 mo } \\
\text { (mean } 28 \mathrm{mo} \text { ) }\end{array}$ & none given & $\begin{array}{l}\text { rigidity and } \\
\text { hypokinesia } \\
\text { improved in } \\
92 \% \text { each; } \\
\text { tremor in } 81 \%\end{array}$ & not mentioned & $\begin{array}{l}\text { gait \& speech } \\
\text { improved }\end{array}$ & $\begin{array}{l}\text { "disappeared } \\
\text { more of less } \\
\text { completely" }\end{array}$ & $\begin{array}{l}\text { hemianopia in } \\
14 \%\end{array}$ & $\begin{array}{l}\text { medications } \\
\text { reduced "in most" } \\
\text { by } 50-75 \%\end{array}$ \\
\hline $\begin{array}{l}\text { Laitinen et al. } \\
1995[28]\end{array}$ & $\begin{array}{l}259 \text { (contains } \\
\text { patients in } 1992 \\
\text { study); } 12 \text { bilat, } \\
18+\text { thalamo- } \\
\text { tomy, } 9 \text { repeats }\end{array}$ & $\begin{array}{l}\text { no systematic } \\
\text { F/U }\end{array}$ & $\begin{array}{l}\text { "good results" } \\
\text { in } 212 \text {, fair in } \\
36, \text { poor in } 11, \\
\text { no improvement } \\
\text { in } 11\end{array}$ & $\begin{array}{l}96 \% \text { good to } \\
\text { fair relief of all } \\
\text { symptoms }\end{array}$ & not mentioned & not emphasized & $\begin{array}{l}\text { + includes } \\
\text { dyskinesias }\end{array}$ & $\begin{array}{l}4 \% \text { homony- } \\
\text { mous scotoma } \\
\text { (none in last } \\
100 \text { ) }\end{array}$ & \\
\hline $\begin{array}{l}\text { Iacono et al. } \\
1995 \text { [18]; see } \\
\text { also [17] }\end{array}$ & $\begin{array}{l}\text { 126; } 68 \text { bilat- } \\
\text { eral; mean F/U } \\
4.5 \text { mo }\end{array}$ & $\begin{array}{l}\text { UPDRS of } \\
\text { videotaped "on" } \\
\text { assessments, } \\
\text { unilateral and } \\
\text { bilateral data } \\
\text { lumped } \\
\text { together, much } \\
\text { of the data is } \\
\text { uninterpretable }\end{array}$ & $\begin{array}{l}\mathrm{H} \& \mathrm{Y} \text { pre } 3.4 \text { to } \\
2.0 \text { post }\end{array}$ & $\begin{array}{l}\text { tremor } \\
\text { improved } 65 \% \text {, } \\
\text { rigidity } 70 \%\end{array}$ & $?$ & $\begin{array}{l}\text { posture, gait, } \\
\text { and postural sta- } \\
\text { bility improved } \\
50-57 \%\end{array}$ & $\begin{array}{l}\text { "all patients } \\
\text { noted freedom } \\
\text { from .. dyskine- } \\
\text { sias" }\end{array}$ & $\begin{array}{l}\text { permanent } \\
\text { hemianopia 2, } \\
\text { hemiparesis } 3\end{array}$ & $\begin{array}{l}\text { There are many } \\
\text { inconsistencies in this } \\
\text { data especially if one } \\
\text { compares it to [17] } \\
\text { where bilateral proce- } \\
\text { dures are not even } \\
\text { mentioned! }\end{array}$ \\
\hline $\begin{array}{l}\text { Sutton et al. } \\
1995[56]\end{array}$ & $\begin{array}{l}5 ; 3 \text { unilateral } \\
\text { with } 2 \text { repeats, } \\
2 \text { bilateral }\end{array}$ & $\begin{array}{l}\text { UPDRS off/on, } \\
\text { timed tasks }\end{array}$ & $\begin{array}{l}\text { no signif. } \\
\text { differences }\end{array}$ & no change & no change & no change & $\begin{array}{l}\text { dyskinesias } \\
\text { improved in } 2 \\
\text { and dystonia in } \\
1\end{array}$ & $\begin{array}{l}\text { depression 2, } \\
\text { visual field 2, } \\
\text { increased freez- } \\
\text { ing 1, worsened } \\
\text { speech 1, swal- } \\
\text { lowing } 1\end{array}$ & $\begin{array}{l}2 \text { patients H\&Y } 5 \text { on } \\
\& \text { off after only } 4 \text { and } \\
5 \text { yrs of disease } \\
\text { suggests alternative } \\
\text { diagnoses (?MSA) }\end{array}$ \\
\hline $\begin{array}{l}\text { Dogali et al. } \\
1995 \text { [9] }\end{array}$ & $\begin{array}{l}18 \text { compared to } \\
7 \text { unoperated } \\
\text { patients; F/U } 12 \\
\text { mo }\end{array}$ & $\begin{array}{l}\text { UPDRS and } \\
\text { CAPIT (timed } \\
\text { scores rated } \\
\text { blindly from } \\
\text { video) }\end{array}$ & $\begin{array}{l}\text { "off” UPDRS } \\
\text { improved by } \\
65 \% \text {; "on" } \\
\text { scores also } \\
\text { improved ; no } \\
\text { signif. changes } \\
\text { in unoperated } \\
\text { group }\end{array}$ & $\begin{array}{l}\text { "off" CAPIT } \\
\text { timed scores } \\
\text { improved by } \\
38.2 \% \text {, } \\
\text { UPDRS scores } \\
\text { not given }\end{array}$ & $\begin{array}{l}\text { "off" CAPIT } \\
\text { timed scores } \\
\text { improved by } \\
24.2 \%, \\
\text { UPDRS scores } \\
\text { not given; "on" } \\
\text { scores improved }\end{array}$ & $\begin{array}{l}\text { "off" CAPIT } \\
\text { walk scores } \\
\text { improved by } \\
45 \% \text {; "on" } \\
\text { scores improved }\end{array}$ & $\begin{array}{ll}\text { "resolution of ... } & t \\
\text { contralateral } & \mathrm{s} \\
\text { dyskinesias" - } & \mathrm{c} \\
\text { no data given } & \mathrm{s} \\
& \mathrm{p}\end{array}$ & $\begin{array}{l}\text { transient hyper- } \\
\text { sexuality in } 1 \text {, } \\
\text { contralat. MCA } \\
\text { stroke } 7 \text { mos } \\
\text { post-op in } 1\end{array}$ & \\
\hline $\begin{array}{l}\text { Fazzini et al. } \\
1997 \text { [11] }\end{array}$ & $\begin{array}{l}11 \text { (all from the } \\
\text { Dogali report) } \\
\text { F/U for } 2 \text { yr in } \\
1,3 \text { yr in } 5 \text { and } \\
4 \text { yr in } 5 \text { ( } 4 \text { oth- } \\
\text { ers had second } \\
\text { procedure and } 3 \\
\text { were lost to } \\
\text { F/U) }\end{array}$ & as above & $\begin{array}{l}\text { ADL and motor } \\
\text { scores remained } \\
\text { signif. improved } \\
\text { and did not } \\
\text { change over } 3 \\
\text { yrs of } F / U\end{array}$ & $\begin{array}{l}\text { no decline in } \\
\text { CAPIT } \\
\text { improvements } \\
\text { over the } F / U \\
\text { period }\end{array}$ & $\begin{array}{l}\text { some "minor" } \\
\text { deterioration in } \\
\text { ipsi CAPIT } \\
\text { scores over the } \\
\text { F/U }\end{array}$ & not given & $\begin{array}{l}\text { "dyskinesias did - } \\
\text { not return on the } \\
\text { operated side" }\end{array}$ & & $\begin{array}{l}\text { some of the specific } \\
\text { scores are somewhat } \\
\text { difficult to compre- } \\
\text { hend - i.e., post-op } \\
\text { "off" UPDRS scores } \\
\text { are extremely low in } \\
\text { several patients (e.g., } \\
1,6,0,2,0 \text { at various } \\
\text { F/U times with pre- } \\
\text { op } 39,63,43,55,49 \\
\text { respectively) }\end{array}$ \\
\hline
\end{tabular}


Table 1 Cont.

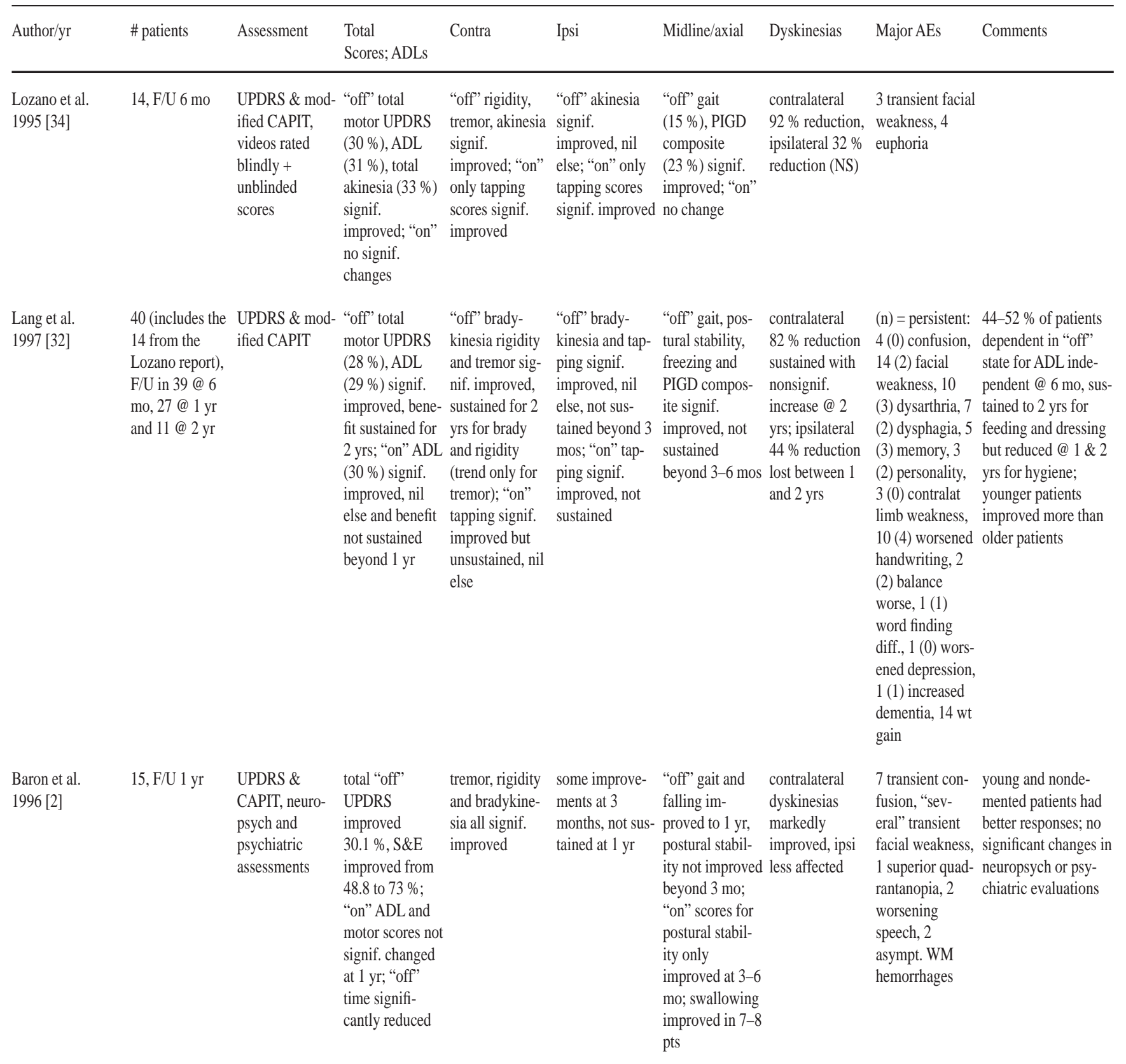


Table 1 Cont.

\begin{tabular}{|c|c|c|c|c|c|c|c|c|c|}
\hline Author/yr & \# patients & Assessment & $\begin{array}{l}\text { Total } \\
\text { Scores; ADLs }\end{array}$ & Contra & Ipsi & Midline/axial & Dyskinesias & Major AEs & Comments \\
\hline $\begin{array}{l}\text { Johansson et al. } \\
1997 \text { [20] }\end{array}$ & $\begin{array}{l}22, \text { F/U } 1 \text { yr }(2 \\
\text { had repeat oper- } \\
\text { ations) }\end{array}$ & $\begin{array}{l}\text { selected } \\
\text { UPDRS items } \\
\text { on visual ana- } \\
\text { logue scale, } \\
\text { timed tests and } \\
\text { videos per- } \\
\text { formed several } \\
\text { times in a single } \\
\text { day with evalua- } \\
\text { tions unique to } \\
\text { this study and } \\
\text { patients not } \\
\text { assessed at } \\
\text { specified times } \\
\text { related to meds } \\
\text { (i.e., no true } \\
\text { "off" and "on" } \\
\text { assessments) }\end{array}$ & $\begin{array}{l}\text { not evaluated; } \\
\% \text { of day in var- } \\
\text { ious fluctua- } \\
\text { tional states } \\
\text { evaluated: no } \\
\text { change in "off" } \\
\text { occasions, "con- } \\
\text { siderable" } \\
\text { reduction in "on } \\
\text { +" time and pro- } \\
\text { portional } \\
\text { increase in "on" } \\
\text { time }\end{array}$ & $\begin{array}{l}\text { maximum val- } \\
\text { ues of tremor } \\
\text { and RAM of } \\
\text { hands signif } \\
\text { improved but } \\
\text { only a trend for } \\
\text { reduction of } \\
\text { median values } \\
\text { (unusual analy- } \\
\text { sis), timed tests } \\
\text { unchanged }\end{array}$ & unchanged & $\begin{array}{l}\text { rising from } \\
\text { chair, posture } \\
\text { and freezing not } \\
\text { improved (prob- } \\
\text { ably all "on" } \\
\text { features) }\end{array}$ & $\begin{array}{l}12 \text { of } 13 \text { with } \\
\text { dyskinesias } \\
\text { "completely } \\
\text { vanished" at } 4 \\
\text { mo, ipsilateral } \\
\text { dyskinesias also } \\
\text { improved }\end{array}$ & $\begin{array}{l}2 \text { confusion, } \\
\text { dysarthria, } 1 \\
\text { scotoma, } 1 \\
\text { marked worsen- } \\
\text { ing of dysarthria } \\
\text { and gait }\end{array}$ & $\begin{array}{l}\text { evaluations are idio- } \\
\text { syncratic to this } \\
\text { study, no true assess- } \\
\text { ment of effect of } \\
\text { surgery on "off" } \\
\text { period features }\end{array}$ \\
\hline $\begin{array}{l}\text { Kishore et al. } \\
1997 \text { [23] }\end{array}$ & $\begin{array}{l}24, \mathrm{~F} / \mathrm{U} \text { up to } \\
1 \mathrm{yr}(11 \mathrm{pts})\end{array}$ & $\begin{array}{l}\text { UPDRS \& } \\
\text { CAPIT, Purdue } \\
\text { pegboard (PPB) } \\
\text { (blinded) }\end{array}$ & $\begin{array}{l}\text { signif. improve- } \\
\text { ment in "off" } \\
\text { ADL and motor } \\
\text { UPDRS and } \\
\text { "on" ADL } \\
\text { (trend for } \\
\text { motor) }\end{array}$ & $\begin{array}{l}\text { "off" tremor } \\
(79 \%), \text { rigidity } \\
(55 \%), \text { bradyki- } \\
\text { nesia }(43 \%), \\
\text { and PPB }(49 \%) \\
\text { signif. } \\
\text { improved; "on" } \\
\text { rigidity (38\%) } \\
\text { and PPD (20\%) }\end{array}$ & $\begin{array}{l}\text { "off" tremor and } \\
\text { bradykinesia } \\
\text { signif. } \\
\text { improved; "on" } \\
\text { PPB }\end{array}$ & $\begin{array}{l}\text { "off" gait and } \\
\text { postural stabil- } \\
\text { ity improved } \\
\text { (not "on") }\end{array}$ & $\begin{array}{l}\text { contralateral } \\
(76 \%) \text { and ipsi- } \\
\text { lateral }(41 \%) \\
\text { dyskinesias sig- } \\
\text { nif. improved }\end{array}$ & $\begin{array}{l}1 \text { delayed hem- } \\
\text { orrhage and } \\
\text { death, } 3 \text { sco- } \\
\text { tomas, } 1 \text { facial } \\
\text { weakness, } 2 \\
\text { transient hemi- } \\
\text { paresis }\end{array}$ & $\begin{array}{l}\text { age correlated posi- } \\
\text { tively with improve- } \\
\text { ment in "off" UPDRS } \\
\text { motor scores }\end{array}$ \\
\hline $\begin{array}{l}\text { Uitti et al. } \\
1997 \text { [62] }\end{array}$ & 20, F/U 3 mo & $\begin{array}{l}\text { UPDRS \& } \\
\text { CAPIT, detailed } \\
\text { neuropsych test- } \\
\text { ing }\end{array}$ & $\begin{array}{l}\text { "off" and "on" } \\
\text { UPDRS motor } \\
\text { scores signif. } \\
\text { improved; } \\
\text { "ADL" (? off vs } \\
\text { on) signif. } \\
\text { improved }\end{array}$ & $\begin{array}{l}\text { "off" timed } \\
\text { tasks improved, } \\
\text { other motor } \\
\text { scores not given }\end{array}$ & $\begin{array}{l}\text { no change in } \\
\text { timed scores }\end{array}$ & $\begin{array}{l}\text { severe gait } \\
\text { disturbances } \\
\text { pre-op in 6/11 } \\
\text { were markedly } \\
\text { improved }\end{array}$ & $\begin{array}{l}\text { Goetz score } \\
\text { (mean only } 1.4 \\
\text { pre-op) not } \\
\text { improved, Mayo } \\
\text { dyskinesia score } \\
\text { improved (not } \\
\text { divided into } \\
\text { contra vs ipsi) }\end{array}$ & $\begin{array}{l}3 \text { transient con- } \\
\text { fusion, } 1 \text { urinary } \\
\text { incontinence }\end{array}$ & $\begin{array}{l}\text { L lesions in R handed } \\
\text { patients: mild decline } \\
\text { in word generation } \\
\text { (no other neuropsych } \\
\text { changes); elderly } \\
\text { patients responded as } \\
\text { well as younger }\end{array}$ \\
\hline
\end{tabular}


Table 1 Cont.

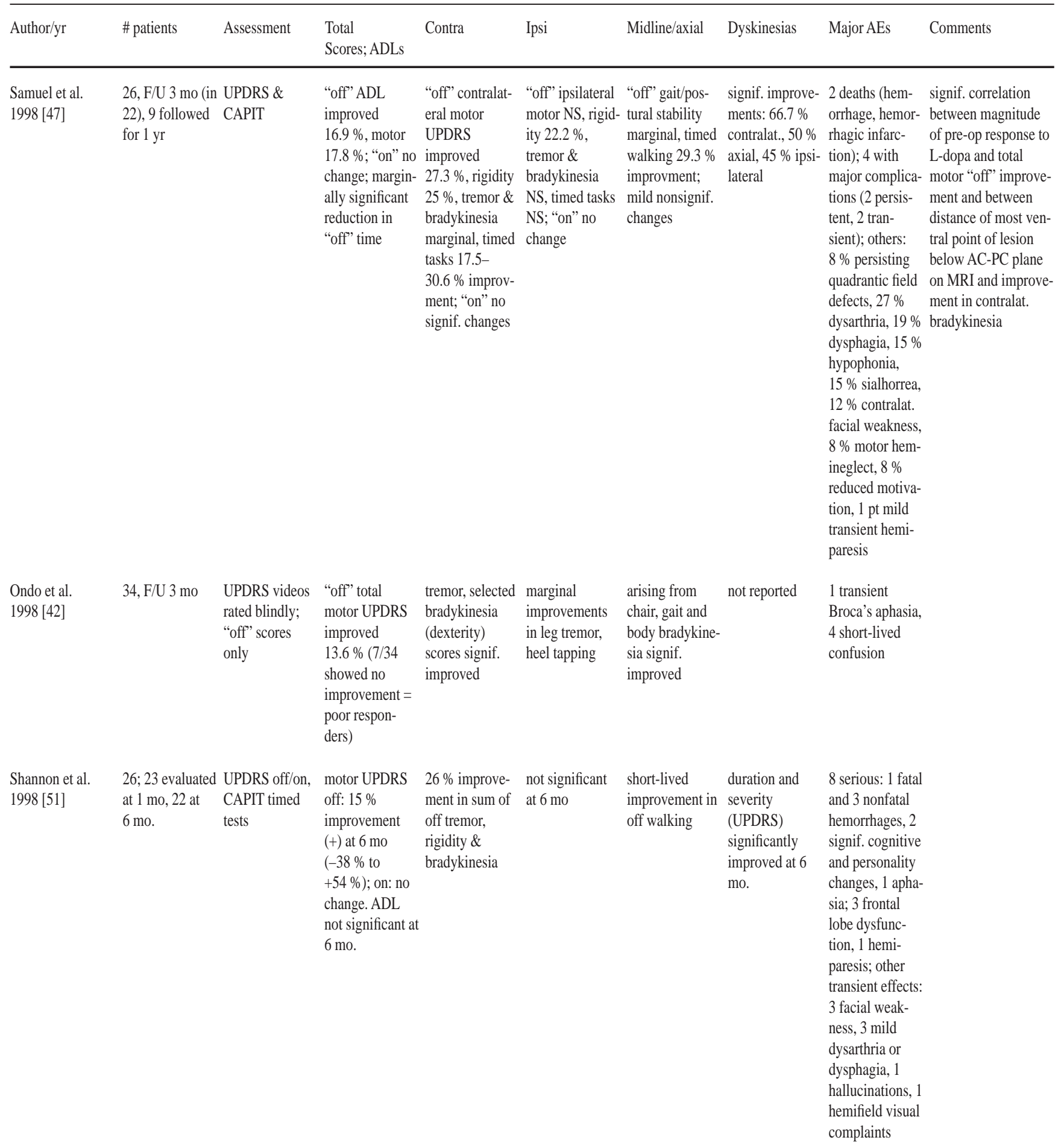


Table 1 Cont.

\begin{tabular}{|c|c|c|c|c|c|c|c|c|c|}
\hline Author/yr & \# patients & Assessment & $\begin{array}{l}\text { Total } \\
\text { Scores; ADLs }\end{array}$ & Contra & Ipsi & Midline/axial & Dyskinesias & Major AEs & Comments \\
\hline $\begin{array}{l}\text { Giller et al. } \\
1998 \text { [13] }\end{array}$ & $\begin{array}{l}55 ; 49 \text { unilat- } \\
\text { eral, } 8 \text { staged } \\
\text { and } 3 \text { simultane- } \\
\text { ous bilateral }\end{array}$ & UPDRS off/on & $\begin{array}{l}\text { off motor scores } \\
\text { "significantly } \\
\text { improved" } \\
\text { (declined by } \geq 5 \\
\text { points) at } 2 \text { mo. } \\
\text { (n=35) in } \\
71 \% \text {, no change } \\
\text { in } 20 \% \text { and } \\
\text { worse in } 9 \% \text {; at } \\
6 \text { mo. }(\mathrm{n}=27) \text { : } \\
78 \%, 11 \%, \\
7 \% \text {; at } 12 \text { mo. } \\
\text { (n=12): } \\
75 \%, 17 \% \text {, } \\
8 \% \text {. On scores } \\
\text { improved but } \\
\text { "less promi- } \\
\text { nent". ADLs not } \\
\text { mentioned. }\end{array}$ & not mentioned & not mentioned & not mentioned & $\begin{array}{l}70 \% \text { reduction } \\
\text { in total dyskine- } \\
\text { sia score and } \\
89 \% \text { reduction } \\
\text { in contralateral } \\
\text { dyskinesias }\end{array}$ & $\begin{array}{l}8 \text { (7 bilateral) } \\
\text { had distur- } \\
\text { bances of } \\
\text { speech or oral } \\
\text { function; } 1 \text { sig- } \\
\text { nificant and } 2 \\
\text { mild hemipare- } \\
\text { sis, } 1 \text { transient } \\
\text { confusion, 1 } \\
\text { superficial } \\
\text { infection, 1 } \\
\text { change in cogni- } \\
\text { tion }\end{array}$ & $\begin{array}{l}\text { report emphasized } \\
\text { imaging technique; } \\
\text { more detailed clinical } \\
\text { report to come }\end{array}$ \\
\hline $\begin{array}{l}\text { Scott et al. } \\
1998[50]\end{array}$ & $\begin{array}{l}\text { 20; } 12 \text { unilat- } \\
\text { eral, } 8 \text { bilateral }\end{array}$ & $\begin{array}{l}\text { UPDRS on/off, } \\
\text { neuropsychiatric } \\
\text { studies }\end{array}$ & $\begin{array}{l}\text { Improvements: } \\
\text { Off: } \\
\text { Unilateral-motor } \\
29 \% \text {, ADL } 15 \% \text {; } \\
\text { Bilateral-motor } \\
37 \% \text {, ADL } 44 \% \text {; } \\
\text { On: } \\
\text { Unilateral-motor } \\
27 \% \text {, ADL } 28 \% \text {; } \\
\text { Bilateral-motor } \\
47 \% \text {, ADL } 30 \% \text {. }\end{array}$ & $\begin{array}{l}\text { Not given } \\
6 ; \\
6 ; \\
6\end{array}$ & Not given & Not given & $\begin{array}{l}\text { Unilat: reduced } \\
\text { by } 73 \% \text {; Bilat } \\
\text { reduced by } \\
88 \%\end{array}$ & $\begin{array}{l}\text { Unilateral (12): } \\
\text { Hemiparesis } 1 \\
\text { Visual field defect } \\
1 \\
\text { Dysarthria 1 } \\
\text { Weight gain } 7 \\
\\
\text { Bilateral (8): } \\
\text { Dysarthria 3 } \\
\text { Hypersalivation } 1 \\
\text { Fatigue, confu- } \\
\text { sion, significant } \\
\text { cognitive decline } 1 \\
\text { Weight gain } 5 \\
\text { Falling } 1\end{array}$ & \\
\hline
\end{tabular}

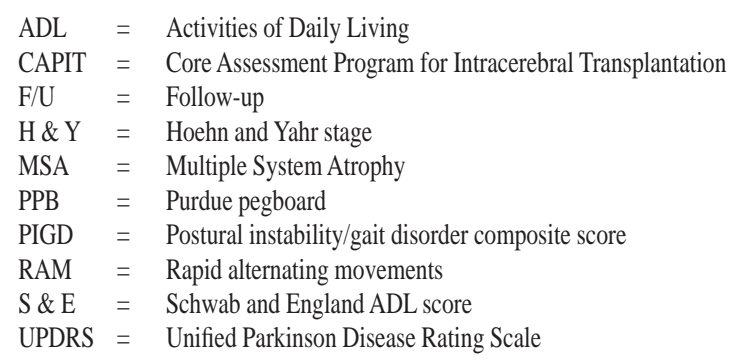

* For inclusion in this table a study had to provide some information on most items listed in the column headings. However, the quality of this data was quite variable from study to study. 


\section{Total UPDRS (parts II \& III)}

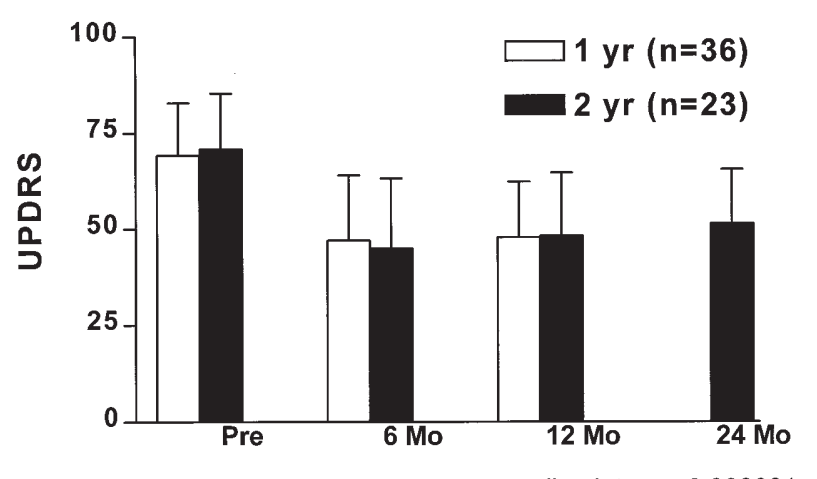

a

all points $p<0.000001$

Fig. 1a Total (parts II \& III) UPDRS off period scores in 2 overlapping follow-up groups, those reaching 1 year $(n=36)$ and 2 year $(n=23)$ follow-up times. $\mathrm{p}<0.00001$ for all follow-up times compared to baseline.

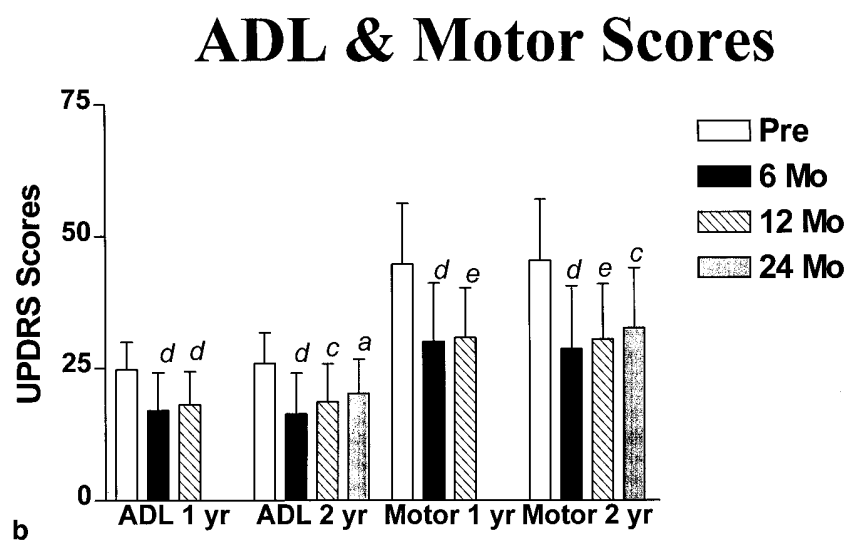

Fig. 1b Total ADL (part II) and Motor (part III) UPDRS off period scores in the 1 year and 2 year follow-up groups. For this and subsequent figures the letter above the bar indicates level of significance as follows: $\mathrm{a}=\mathrm{p}<0.005 ; \mathrm{b}=\mathrm{p}<0.001 ; \mathrm{c}=\mathrm{p}<0.0001 ; \mathrm{d}=\mathrm{p}<0.00001 ; \mathrm{e}=$ $\mathrm{p}<0.000001$.

has a pronounced effect on levodopa-induced dyskinesias. Most studies demonstrate a reduction in "off" period parkinsonism with all major features of the disorder improving on the side contralateral to the surgery. One study found that gait and trunk movements improved even more than contralateral limb movements; however, the evaluation was performed only 1 week after surgery [41]. We have previously reported that the benefit is sustained for over 2 years [32] and Fazzini et al. described persistent benefit up to 4 years after surgery in a small number of patients [11]; however, their follow-up parkinsonian scores are difficult to reconcile with the expected disease severity in these late stage patients.
Figures $1-4$ provide a summary of the most recent followup data on our initial 40 patients evaluated in detail over the first 2 post-operative years with assessments in a practically defined "off" state (at least 12 hours after their last dose of medication) and in the best "on" state. Both total ADL and motor "off" UPDRS scores improved by approximately $30 \%$

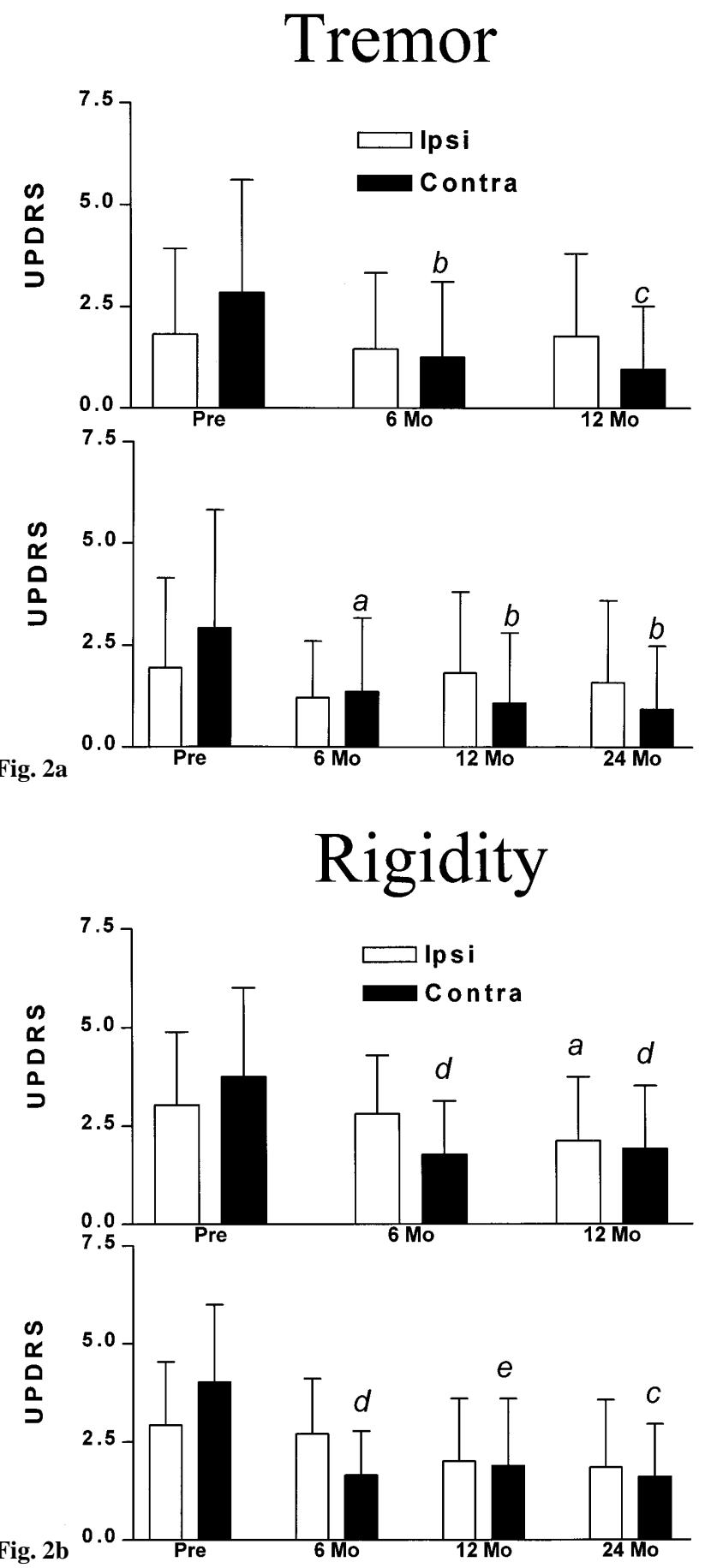




\section{Akinesia}

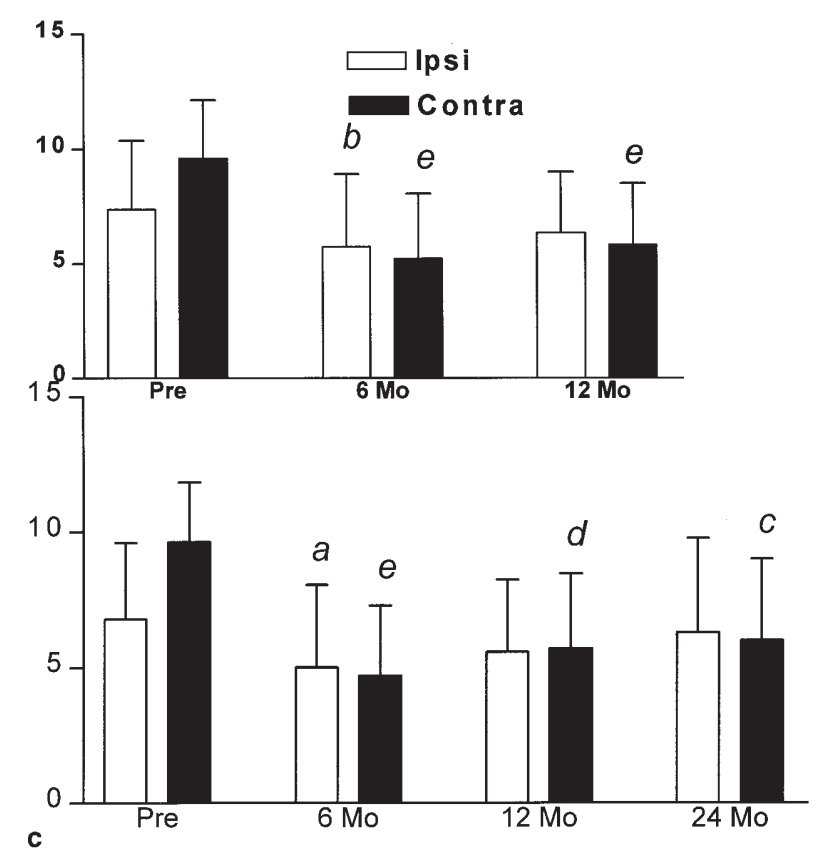

Fig. 2 a-c Composite scores for off period tremor (A), rigidity (B) and akinesia (C) calculated as reported previously [32, 34] ipsilateral (ipsi) and contralateral (contra) to the pallidotomy in the 1 year (top) and 2 year (bottom) follow-up groups.

at 6 months (39 patients; data reported previously [32]). This improvement is similar to the change we had recorded in our first 14 patients using randomized videotapes rated by observers blinded to the treatment status [34]. These changes were generally sustained at the 1 (36 patients) and 2 (23 patients) year marks ( 2 year follow-up: ADL $22 \%, \mathrm{p}<0.005$; motor $28.3 \%, p<0.001$ ) (Figs. 1 A \& B). All features of parkinsonism in the contralateral limbs improved significantly and remained improved for at least 2 years of follow-up (rigid-

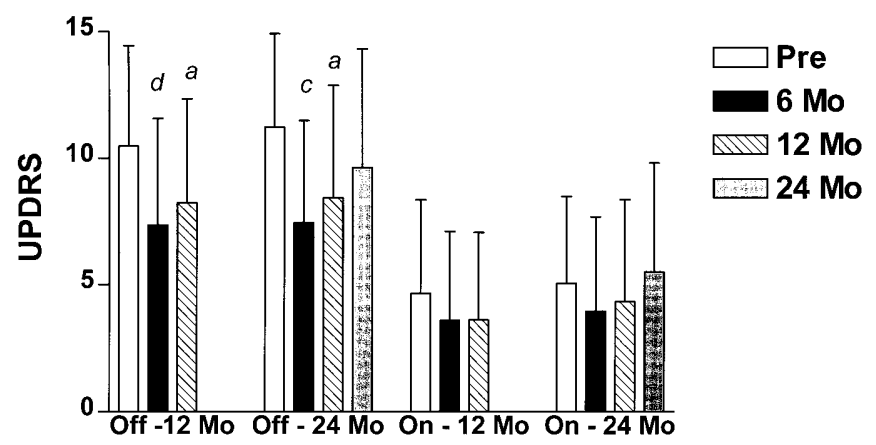

Fig. 3 Off- and on-period postural stability/gait disorder composite scores calculated as reported previously [32] in the 1 year (groupings of 3 bars) and 2 year (groupings of 4 bars) follow-up groups. ity $60 \%$, p < 0.001 ; akinesia $37.7 \%$, p $<0.001$; tremor $67.1 \%$, $\mathrm{p}<0.01$ ) (Fig. 2). Mild changes on the ipsilateral side (Fig. 2) and improvement in axial features (postural stability \& gait disorder composite (PIGD) score) (Fig. 3) were not sustained beyond 6 months and 1 year, respectively. On-period dyskinesias were improved by greater than $80 \%$ contralateral to the surgery and $50 \%$ on the ipsilateral side. Contralateral dyskinesias remained markedly improved at 2 years $(69.1 \%$, $\mathrm{p}<0.0001$ ) while the benefit to ipsilateral dyskinesias was lost between 1 and 2 years (Fig. 4). On-period parkinsonism was not improved with the exception of ADL and tapping scores, both of which were probably a reflection of the reduction in dyskinesias. On-period PIGD score at 2 years was worse $(-8.7 \%)$ than before surgery (Fig. 3). The procedure was generally well tolerated although side effects (mostly transient) were not uncommon (see [32] for details).

A small number of studies have evaluated performance on motor tasks aside from clinical rating scales. Jankovic et al. [19] demonstrated improvements in "off" period contralateral simple and complex reaction times and movement time. Bennett et al. [4] documented a reduction in the duration of movement and time spent in deceleration but at the "cost" of deterioration in movement patterning (reach to grasp movements to objects of differing sizes). Pfann and colleagues [44] found no change in "on" period peak velocity or other mean "on" motor performance measures studied.

The effect of pallidotomy on response to levodopa has been evaluated beyond the simple assessment of "on" period clinical scores. Merello et al. [39] found a non-significant reduction (by $50 \%$ ) in the latency to benefit from a single oral dose of levodopa while the duration of effect was significantly

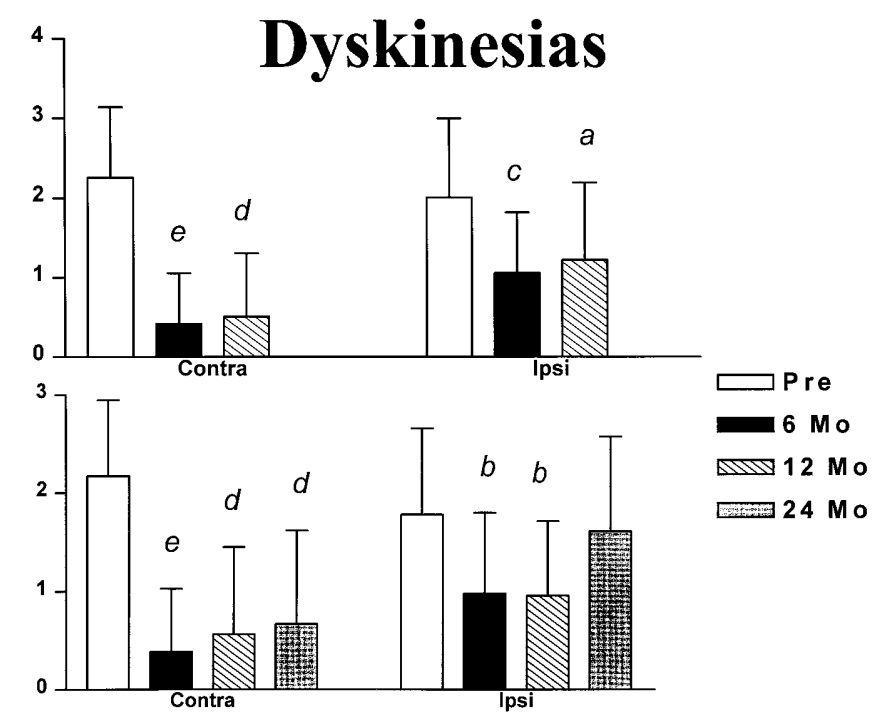

Fig. 4 On-period dyskinesia scores calculated as reported previously [32, 34] ipsilateral (ipsi) and contralateral (contra) to the pallidotomy in the 1 year (top) and 2 year (bottom) follow-up groups. 
prolonged bilaterally. Studying responses to single oral doses and intravenous infusions of levodopa, Skalabrin et al. [52] found changes in motor benefit and dyskinesias that suggested that pallidotomy significantly widens the therapeutic window of L-dopa in PD.

\section{Predictive factors}

In general, most studies have not found any reliable clinical predictive factors related to the subsequent response to pallidotomy. Like Baron et al. [2] we found that the younger patients tended to do better. However, Kishore et al. [23] found that age correlated positively with the improvement seen in off-period motor scores and Uitti et al. [62] reported that elderly patients responded as well as younger ones. Recently, Desaloms et al. [8] evaluated the effect of preoperative MRI findings on clinical outcome. Mild or moderate degrees of cortical atrophy, periventricular lucencies and deep white matter lesions had no effect while status cribriformis (multiple and bilateral enlarged Virchow-Robin spaces) and lacunes predicted less improvement in UPDRS ADL "off" scores at 6 months as well as higher incidence of transient mental status abnormalities immediately postoperatively.

Response to medication may be an important predictor of benefit. Samuel et al. [47] found a significant correlation between the magnitude of preoperative response to levodopa and the improvement in total motor off UPDRS scores following pallidotomy. Likewise, Kazumata et al. [22] found that clinical outcome correlated significantly with preoperative measures of CAPIT score change in response to levodopa. In addition, they found that the response correlated with preopertive measures of lentiform glucose metabolism using fluorodeoxyglucose (FDG) PET. Although this observation is of pathophysiological importance it is of little practical widescale use in predicting who should or should not undergo surgery. Merello et al. [38] reported that the appearance of abnormal involuntary movements during macrostimulation or thermolesioning of the GPi correlated with better outcomes as measured by UPDRS motor items and CAPIT timed tests.

We have attempted to determine whether we could predict the outcome at 6 months following unilateral pallidotomy in 36 patients using the preoperative clinical profile. The response to surgery was defined as the difference between the 6 month score ("on" and "off" UPDRS composite scores and dyskinesia scores) and the baseline. Multivariate regression analysis of the entire dataset demonstrated that no individual preoperative factor or combination of factors were able to predict the difference scores at 6 months. We then distinguished 2 groups of subjects, those in the top $25^{\text {th }}$ percentile of response (with respect to the rating item of interest) and those in the bottom $25^{\text {th }}$ percentile, hoping that by selecting those who did relatively better and those who did relatively worse, predictive factors could be defined. Patients with a better response of the UPDRS preoperative motor score to levodopa had a greater improvement in total "off-period" motor score in response to pallidotomy. Those with more severe dyskinesias before surgery had the greatest reduction in dyskinesias due to a "floor effect". No other specific factor, including age, predicted responses. These results suggest that the response of our carefully selected patient group was sufficiently uniform that no predictive factors apart from preoperative response to levodopa could be determined. It may also suggest that our entry criteria were too conservative and that some prospective patients who were excluded could have obtained a good response. On the other hand, faced with restricted availability or limited health care resources, our entry criteria (continued good response to levodopa but with disabling fluctuations and dyskinesias and absence of significant cognitive dysfunction and other general medical problems) predict a high likelihood of a beneficial response to pallidotomy.

\section{Neuropsychological effects}

The neuropsychological effects of unilateral pallidotomy remain somewhat controversial. Baron et al. [2] found that none of the 25 neuropsychological variables tested in their study showed significant changes in their group of 12 patients evaluated between 1 and 6 months and 10 and 12 months postoperatively compared to baseline. However, they noted executive and memory declines on the Dementia Rating Scale in 2 patients who had iatrogenic small frontal hematomas. In abstract form, Riordan et al. [46] and Stebbins et al. [54] report further decline in executive functions, such as cognitive flexibility, working memory, and abstract reasoning in 16 and 9 patients, respectively. Soukup et al. [53] found no significant deterioration of cognitive abilities in their group of 14 patients 3 months post-operatively. Although mostly in abstract form, deficits have been fairly consistently observed in verbal phonemic or semantic fluencies, especially after left-sided lesions [1, 35-37, 45, 46, 58, 59]. Inconsistencies are related to whether one or both measures of fluency are declining. Scott et al. [50] also reported verbal memory declines in their first 3 of $12(25 \%)$ unilateral pallidotomy patients (side of lesion was not specified) but noted that their lesions were larger and extended vertically. In abstract form, Riordan et al. [46] also found verbal memory declines at 3 months followup in 10 patients with left-sided lesions. Perrine et al. [43] showed no significant changes in their group of 28 patients when compared to an unoperated control group of 10 patients, although 5 patients significantly declined (> 1.5 SDs) on one of the neuropsychological tests performed. However, Stebbins et al. [55] reported that tasks tapping working memory capac- 
ity as well as other aspects of frontal executive functioning and visuoconstructional functions were performed poorly in 13 patients studied 1 year after surgery. Indeed, they found performance on any task with strong working memory demands declined in the operated group but not in a parkinsonian control group. Furthermore, frontal behavioral dyscontrol (i.e., sexual disinhibition, frontal executive syndromes) also has been observed, albeit rarely $[9,11,51]$.

In our experience in 42 unilateral pallidotomy patients evaluated in the on state [59], the procedure was associated with a modest improvement in sustained attentional capacity, possibly due to the improvement in dyskinesias. Using alternate test forms for follow-up assessments, it was found that left hemisphere lesions led to a loss of verbal learning (average decline was $-2.2 \mathrm{SD}$ on the California Verbal Learning Test) and of verbal phonemic fluency $(-1.6 \mathrm{SD})$ in $60 \%$ of 15 cases at 3-6 months post-operatively. These impairments tended not to recover by their 12 month follow-up. Right-sided lesions led to a transient loss of visuospatial constructional abilities on the R/O Complex Figure $(n=8$, average decline was $-3.5 \mathrm{SD}$ ), which fully resolved by 12 months in all but 1 patient. Semantic fluency was reduced (> 1SD) in 7 of $27(26 \%)$ of all patients. Evidence of further decline of frontal executive functioning (i.e., working memory, initial encoding, ability to plan and organize) was observed with "indirect" tests but not on a "direct" test of executive functions (Conditional Associative Learning). Various types and degrees of frontal behavioral change (i.e., emotional lability, impulsivity, sexual disinhibition, environmental dependency) were reported in approximately $25 \%$ of patients $(n=39)$ which occasionally increased dependence on caregivers or negatively affected patients' relationships with caregivers. In general, these behavioral changes restricted patients' ability to function properly at work or in social settings. Lack of insight into these changes were noted in some patients, making behavioral management more difficult. These changes were outweighed by the positive clinical benefits obtained by the surgery.

The reason for the discrepancies in these outcome studies may relate to differences in patient populations, study designs or size and location of lesions. Specifically, studies that report mostly negative findings $[2,43,50,53]$ appear to be limited by small sample sizes, not making use of alternate test forms to control for practice effects, combining data from right and left hemisphere pallidotomy surgeries for analyses of potentially lateralizing tests, employing insensitive tests, or combining different follow-up periods. Further neuropsychological studies, particularly with additional MRI reconstruction of the lesion location and laterality have revealed significant correlations (Lombardi, Gross, Trépanier, Lozano, Lang, \& Saint-Cyr, in preparation). Such detailed and controlled studies will be required from other centers in order to define the potential cognitive consequences of posteroventromedial pallidotomy.

\section{Imaging}

A number of studies have evaluated patients before and after pallidotomy attempting to correlate response to various imaging parameters. PET studies have also attempted to define the physiological mechanisms underlying the response based on changes found in scans performed after surgery compared to baseline. Kraus et al. found that the size and location of the lesion within the GPi did not correlate with the clinical response as measured by a global outcome score or parkinsonian rating scales [26]. Kazumata et al. [22] also found no significant correlation between lesion position or volume on MRI and the clinical outcome of their 22 patients, nor did they find a correlation between outcome and pallidal neuronal firing rates measured on intra operative microrecording. However, as mentioned previously, clinical outcome did correlate significantly with preopertive measures of FDG/PET lentiform glucose metabolism. Burns et al. [5] carried out 3-dimensional reconstruction of 23 pallidal lesions along with the basal ganglia and optic tract. They found that the lesions were more dorsal in men than in women. However, they found that the clinical outcomes did not correlate with either lesion location relative to the starting point or distances between the pallidal lesion and the putamen, internal capsule, or optic tract. Evaluating MRI scans in 11 patients, Samuel et al. [47] found that the distance of the most ventral point of the pallidotomy lesion below the AC-PC plane was significantly correlated with improvement in contralateral bradykinesia scores. However, there was no correlation between lesion volume and outcome.

Our group [16] has carried out volumetrc imaging in 33 patients to allow quantitative lesion localization in relation both to conventional intraventricular landmarks as well as more anatomically relevant landmarks. Considerable lesion location variation was evident largely due to variation in third ventricular width and the oblique anteromedial to posterolateral course of the internal capsule. Given the excellent clinical benefits and minimal postoperative complications, these results emphasize the need for physiologic corroboration for correct lesion placement. Hierarchical multiple regression analysis was then used to relate lesion position to clinical outcome. Lesion location along the anteromedial to posterolateral axis within the GPi influenced the variance in postoperative off period total UPDRS and on period dyskinesia scores at 6 and 12 months. Within the posteroventral GPi, anteromedial lesions were associated with more improvement in off period contralateral rigidity and on period dyskinesia. Centrally located lesions correlated with better outcome of contralateral akinesia and postural instability/gait disturbance. There was a weak correlation between improvement in contralateral tremor and more posterolateral lesions. Thus, we have found that improvement in specific motor signs in Parkinson's disease following pallidotomy is related to the lesion position within the posteroventral GPi supporting the notion of the segregated 
but parallel organization of specific motor circuits within the basal ganglia. It will be important to apply this type of analysis further to functional imaging studies such as PET or fMRI.

To date, a few groups have demonstrated the effects of pallidotomy (or pallidal stimulation) on cerebral blood flow and metabolism. Grafton et al. [15] reported an increase in regional cerebral blood flow (rCBF) during a simple prehension task in both the supplementary motor area (SMA) and premotor cortex but not primary motor cortex. Interestingly, these patients had not improved significantly from the surgery. Eidelberg et al. [10] have shown that pallidotomy is associated with significant metabolic increase in the primary motor cortex, lateral premotor and dorsolateral prefrontal cortex and that clinical improvement correlated with a covariance pattern (defined on principal components analysis) characterized by postoperative declines in ipsilateral lentiform and thalamic metabolism associated with bilateral increases in metabolism in the SMA [10]. Using a regularly paced free selection joystick paradigm, Samuel et al. [48] demonstrated relative increases in activation of the SMA and dorsolateral prefrontal cortex following pallidotomy. These studies support the concept that pallidotomy reduces the excessive inhibition of thalamocortical circuits which occurs in Parkinson's disease. Changes in cortical activation in response to deep brain stimulation of the GPi [7, 33] and STN [33] also support this model of basal ganglia dysfunction in PD. The similarity of cortical changes induced by pallidotomy and GPi stimulation suggests that the later technique also works by blocking the excessive inhibitory efferent activity of the GPi.

\section{Bilateral pallidotomy}

The role of bilateral pallidotomy remains uncertain. The high incidence of complications such as speech dysfunction and cognitive decline in past studies of bilateral thalamotomy must engender caution when considering bilateral stereotactic ablative procedures. There has been very little reliable data published on the results of bilateral posteroventral medial pallidotomy. Schuurman et al. described substantial benefit of bilateral pallidotomy in 3 patients with typical Parkinson's disease [49]. Interestingly, one of these (with classical resting tremor as well as other features of Parkinson's disease) was resistant to previous levodopa therapy. Scott et al. have reported their results of 8 simultaneous bilateral and 12 unilateral pallidotomies [21]. They found a $53 \%$ improvement in UPDRS scores in the bilateral group compared to $27 \%$ improvement after unilateral pallidotomy. As mentioned above, they reported greater deterioration in verbal fluency after bilateral surgery and one patient had more evidence of global cognitive decline. They also reported a significant fall in diadochokinetic rates and some subjective reports of a wors- ening in pre-existing dysarthria, hypophonia and mild hypersalivation/drooling following bilateral surgery which also suggested changes in speech motor apparatus; however these changes were said not to have had significant functional consequences. Giller et al. [13] reported disappointing clinical results in 8 patients undergoing staged bilateral pallidotomy and although 2 of their 3 patients treated with simultaneous pallidotomy improved (no indication of the degree of this improvement and how it compared to their unilateral group), all 3 developed significant speech impairment which was severe in two.

We have performed 4 staged bilateral pallidotomies. Two of our 4 patients have had substantial cognitive complications although limb parkinsonian features and particularly the disabling levodopa-induced dyskinesias were markedly reduced. A third patient, whose second lesion was purposefully made smaller than in the first 2 cases, tolerated the procedure well with a clear improvement in dyskinesias but little further reduction in the severity of "off" period parkinsonism. Early follow-up in the fourth patient suggested that his response to levodopa had declined although a subsequent report from his neurologist in California has indicated that he was doing well and has clearly benefitted from the second procedure.

\section{Combined unilateral pallidotomy and deep brain stimulation}

In view of concerns regarding the potential for bilateral pallidotomy to result in permanent bulbar or cognitive dysfunction, in patients who have previously undergone unilateral pallidotomy who continue to experience disability from the unoperated side, contralateral deep brain stimulation (DBS) may provide a safer alternative. The advantages of DBS are its reversible and adaptable nature, generally with fewer permanent complications, compared to a standard destructive lesion procedure. We have recently reported our experience using DBS in 4 patients with prior pallidotomy [12]. Electrodes were implanted into the opposite GPi in all and in one, with prominent tremor, two electrodes were implanted, one in the GPi and the other in the Vim thalamus. Blinded clinical evaluations demonstrated improvements in off-period contralateral bradykinesia, rigidity and tremor in all patients. Dyskinesias and freezing episodes were ameliorated in one patient each but dyskinesias were transiently induced in another. The patient with GPi and Vim electrodes had complete resolution of contralateral tremor with thalamic stimulation but less benefit from acute GPi stimulation (although this also improved rigidity and bradykinesia) and so she chose chronic thalamic stimulation.

Generally, most studies of pallidotomy have reported that patients eventually require the same dose of anti-Parkinson 
medications after surgery as before. The same applies to patients treated with pallidal stimulation. On the other hand, to obtain optimal benefit with respect to parkinsonism and dyskinesias from stimulation of the subthalamic nucleus (STN) most patients require a reduction in medications, some substantially. Thus, there may be a conflict in the drug requirements of the two sides if unilateral STN stimulation were to be combined with a previous contralateral pallidotomy. The efficacy of bilateral STN stimulation in a patient with a previous unilateral pallidotomy has not been assessed to date. It is likely that a previous pallidotomy would protect against STN stimulation-induced dyskinesias but how it would influence the beneficial effects of stimulation is uncertain. Given the complex and sometimes unpredictable clinical responses obtained with GPi stimulation $[3,25,60]$ it is likely, that future studies will evaluate the efficacy of bilateral STN stimulation in patients with previous unilateral pallidotomy who are experiencing persistent bilateral (including axial) disability.

\section{Pallidotomy for other parkinsonian disorders}

Our preliminary experiences with pallidotomy in striatonigral degeneration indicated that these patients, with poor levodopa response, were only minimally if at all improved and the benefit may have correlated with the degree of persistent levodopa response [31]. Another of our surgical failures was a gentleman with "atypical parkinsonism" who we reluctantly operated on at the insistence of patient and family (who had traveled many thousands of miles solely for the surgery). Later we learned that he had developed features compatible with a diagnosis of progressive supranuclear palsy (PSP) (N. Quinn, personal communication). We are aware of a small number of other patients with PSP and cortical-basal ganglionic degeneration (CBGD) undergoing pallidotomy at other institutions without benefit. Another patient of ours with possible multiple system atrophy (MSA) but with severe, disabling dyskinesias did obtain a substantial reduction in this one feature. In the uncommon situation that L-dopa-induced limb dyskinesias are a source of disability in patients with MSA, pallidotomy will probably result in a similar degree of reduction in dyskinesias as obtained in PD. Finally, a unique patient with a complex form of levodopa-responsive hemiatrophy-hemiparkinsonism [30] obtained substantial benefit from unilateral pallidotomy. Overall, this experience combined with our data cited above and other reports indicating that the degree of postoperative benefit in Parkinson's disease correlates with the preoperative response to levodopa [22, 47] and the consensus that levodopa-resistant symptoms in Parkinson's disease are not improved by pallidotomy suggests that patients with other parkinsonian disorders may benefit from pallidotomy only in as much as they are responsive to levodopa. However, exceptions to this rule do exist. As mentioned above, one of Schuurman et al.'s patients who benefited from bilateral pallidotomy had failed to respond to levodopa [49]. However, otherwise, this patient had typical Parkinson's disease. Recently two patients, 1 with postanoxic striatal damage [14] and a second with "peripheral trauma-induced parkinsonism" [27], both relatively resistant to levodopa, benefited from unilateral pallidotomy. Further studies in such patients are necessary. In levodopa-resistant patients, prospective evaluation of FDG PET [22] correlating the results with clinical outcome would provide important pathophysiological insights and may help predict which of these candidates should be considered for such surgery in the future.

\section{Concluding remarks}

Pallidotomy provides appropriately chosen patients substantial benefits, particularly with respect to levodopa-induced dyskinesias and off period contralateral parkinsonism. A number of controversial issues remain unanswered. For example, the efficacy of microrecording versus macrorecording and stimulation remains unresolved. This would probably require a randomized study in a small number of centers with equivalent experience using both techniques. Since most groups use one or the other technique exclusively, it is unlikely that the answer to this debate will be forthcoming. A recent paper by Carroll et al. [6] claimed to provide evidence from a review of the literature that micro-electrode recording may have a higher complication rate and does not result in better outcome than image-guided approaches. However, careful assessment of the data reviewed in this report indicates major problems with their analysis of the literature such as inclusion of several overlapping studies by the same authors resulting in counting patients more than once in the calculation of adverse effects and benefit. A recent study evaluating this question found that micro-electrode recording improved the accuracy of lesion placement over CT guidance from $64 \%$ to $100 \%$ based on post-operative MRI scans [61]. Clearly further studies dealing with this important issue are required.

Several other surgical options are being studied in Parkinson's disease. Beneficial effects from fetal transplantation may be considerable but this remains a very experimental approach. Future therapies may involve xenotransplantation, infusions of trophic factors, implantation of encapsulated cells or novel gene therapies; however, it will probably be some time before these are applicable to patients. On the other hand, the efficacy of DBS is well established. Bilateral GPi and STN DBS can result in substantial benefit. However, for many patients this is not a practical option currently. Until DBS surgery and programming and management are more widely available, pallidotomy will continue to play an important role in the 
management of late-stage Parkinson's disease. As these techniques are applied more widely it will be important to compare the results of pallidotomy to DBS. The first pilot comparative study of unilateral pallidotomy to unilateral pallidal DBS by Merello and colleagues [40] demonstrated equivalent effects on UPDRS motor and ADL scores while bilateral hand tapping improved to a greater extent with stimulation and pallidotomy resulted in a greater reduction of dyskinesias. Larger studies, preferably using raters blinded to the treatment arm, will be necessary to evaluate this issue further.

\section{References}

1. Anonymous (1997) The effect of left unilateral pallidotomy on neuropsychological functioning in patients with Parkinson's disease. Journal of the International Neuropsychological Society 3: 207 (Abstract)

2. Baron MS, Vitek JL, Bakay RAE et al. (1996) Treatment of Advanced Parkinson's Disease by Posterior GPi Pallidotomy: 1Year Results of a Pilot Study. Ann Neurol 40: 355-366

3. Bejjani B, Damier P, Arnulf I et al. (1997) Pallidal stimulation for Parkinson's disease - Two targets? Neurology 49: 1564-1569

4. Bennett KM, O'Sullivan JD, Peppard RF, McNeill PM, Castiello U (1998) The effect of unilateral posteroventral pallidotomy on the kinematics of the reach to grasp movement. J Neurol Neurosurg Psychiatry 65: 479-487

5. Burns JM, Wilkinson S, Kieltyka J et al. (1997) Analysis of pallidotomy lesion positions using three-dimensional reconstruction of pallidal lesions, the basal ganglia, and the optic tract. Neurosurgery 41: 1303-1316

6. Carroll CB, Scott R, Davies LE, Aziz T (1998) The pallidotomy debate. Brit J Neurosurg 12: 146-150

7. Davis KD, Taub E, Houser D et al. (1997) Globus pallidus stimulation activates the cortical motor system during alleviation of parkinsonian symptoms. Nature Med 3: 671-674

8. Desaloms JM, Krauss JK, Lai EC, Jankovic J, Grossman RG (1998) Posteroventral medial pallidotomy for treatment of Parkinson's disease: preoperative magnetic resonance imaging features and clinical outcome. J Neurosurg 89: 194-199

9. Dogali M, Fazzini E, Kolodny E et al. (1995) Stereotactic ventral pallidotomy for Parkinson's disease. Neurology 45: 753-761

10. Eidelberg D, Moeller JR, Ishikawa T et al. (1996) Regional metabolic correlates of surgical outcome following unilateral pallidotomy for Parkinson's disease. Ann Neurol 39: 450-459
11. Fazzini E, Dogali M, Sterio D, Eidelberg D, Beric A (1997) Stereotactic pallidotomy for Parkinson's disease: A long-term follow-up of unilateral pallidotomy. Neurology 48 : 1273-1277

12. Gálvez-Jiménez N, Lozano A, Tasker R et al. (1998) Pallidal stimulation in Parkinson's disease patients with a prior unilateral pallidotomy. Can J Neurol Sci 25: 300-305

13. Giller CA, Dewey RB, Ginsburg MI, Mendelsohn DB, Berk AM (1998) Stereotactic pallidotomy and thalamotomy using individual variations of anatomic landmarks for localization. Neurosurgery 42 : 56-62

14. Goto S, Kunitoku N, Soyama N et al. (1997) Posteroventral pallidotomy in a patient with parkinsonism caused by hypoxic encephalopathy. Neurology 49: 707-710

15. Grafton ST, Waters C, Sutton J, Lew MF, Couldwell W (1995) Pallidotomy increases activity of motor association cortex in Parkinson's disease: A positron emission tomographic study. Ann Neurol 37: 776783

16. Gross RE, Lombardi WJ, Lang AE, Duff J, Hutchison WD, Saint-Cyr JA, Tasker RR, Lozano A (1999) Relationship of lesion location to clinical outcome following microelectrode-guided pallidotomy for Parkinson's disease. Brain 122: 405-416

17. Iacono RP, Lonser RR, Ulloth JE, Shima F (1995) Postero-ventral pallidotomy in Parkinson's disease. J Clin Neurosci 2: 140-145

18. Iacono RP, Shima F, Lonser RR et al. (1995) The results, indications, and physiology of posteroventral pallidotomy for patients with Parkinson's disease. Neurosurgery 36: 1118-1127

19. Jankovic J, Ben-Arie L, Schwartz K et al. (1999) Movement and reaction times and fine coordination tasks following pallidotomy. Mov Disord 14: (in press)

20. Johansson F, Malm J, Nordh E, Hariz M (1997) Usefulness of pallidotomy in advanced Parkinson's disease. J Neurol Neurosurg Psychiatry 62: 125-132

21. Johnson KA, Cunnington R, Bradshaw JL et al. (1998) Bimanual co-ordination in Parkinson's disease. Brain 121: 743-753
22. Kazumata K, Antonini A, Dhawan V et al. (1997) Preoperative indicators of clinical outcome following stereotaxic pallidotomy. Neurology 49: 1083-1090

23. Kishore A, Turnbull IM, Snow BJ et al. (1997) Efficacy, stability and predictors of outcome of pallidotomy for Parkinson's disease - Six-month follow-up with additional 1-year observations. Brain 120: 729-737

24. Kopyov O, Jacques D, Duma C et al. (1997) Microelectrode-guided posteroventral medial radiofrequency pallidotomy for Parkinson's disease. J Neurosurg 87: 52-59

25. Krack P, Pollak P, Limousin P, et al. (1998) Opposite motor effects of pallidal stimulation in Parkinson's disease. Ann Neurol 43: 180-192

26. Krauss JK, Desaloms JM, Lai EC et al. (1997) Microelectrode-guided posteroventral pallidotomy for treatment of Parkinson's disease: Postoperative magnetic resonance imaging analysis. J Neurosurg 87: $358-367$

27. Krauss JK, Jankovic J, Lai EC, Rettig GM, Grossman RG (1997) Posteroventral medial pallidotomy in levodopa-unresponsive Parkinsonism. Arch Neurol 54: 1026-1029

28. Laitinen LV (1995) Pallidotomy for Parkinson's Disease. Neurosurgery Clinics of North America 6: 105-112

29. Laitinen LV, Bergenheim AT, Hariz MI (1992) Leksell's posteroventral pallidotomy in the treatment of Parkinson's disease. J Neurosurg 76: 53-61

30. Lang AE (1995) Hemiatrophy, juvenileonset exertional alternating leg paresis, hypotonia, and hemidystonia and adultonset hemiparkinsonism: The spectrum of hemiparkinsonism-hemiatrophy syndrome. Mov Disord 10: 489-495

31. Lang AE, Lozano A, Duff J et al. (1997) Medial pallidotomy in late-stage parkinson's disease and striatonigral degeneration. In: Marsden CD, Obeso JA, Delong M, Ohye Ch (eds) Advances in Understanding the Basal Ganglia and New Surgical Approaches for Parkinson's Disease. Lippincott-Raven, New York, Advances in Neurology 74: 199-211 
32. Lang AE, Lozano AM, Montgomery E et al. (1997) Posteroventral medial pallidotomy in advanced Parkinson's disease. N Engl J Med 337: 1036-1042

33. Limousin P, Greene J, Pollak Pet al. (1997) Changes in cerebral activity pattern due to subthalamic nucleus or internal pallidum stimulation in Parkinson's disease. Ann Neurol 42: 283-291

34. Lozano AM, Lang AE, Galvez-Jimenez N et al. (1995) Effect of GPi pallidotomy on motor function in Parkinson's disease. Lancet 346: 1383-1387

35. Manning C, Bennett J, Wilkniss S, Jones M, Laws E (1997) Comprehensive neuropsychological assesment of cognitive functioning pre- and post-unilateral posteroventral pallditomy. Neurology 48: A252 (Abstract)

36. Marsden CD, Olanow CW (1998) The causes of Parkinson's disease are being unraveled and rational neuroprotective therapy is close to reality. Ann Neurol 44: S189-S196

37. Masterman D, DeSalles A, Baloh RW et al. (1998) Motor, cognitive, and behavioral performance following unilateral ventroposterior pallidotomy for Parkinson disease. Arch Neurol 55: 1201-1208

38. Merello M, Cammarota A, Betti O et al. (1997) Involuntary movements during thermolesion predict a better outcome after microelectrode guided posteroventral pallidotomy. J Neurol Neurosurg Psychiatry 63: 210-213

39. Merello M, Nouzeilles MI, Cammarotta A, Pikielny R, Leiguarda R (1998) Changes in the motor response to acute L-dopa challenge after unilateral microelectrodeguided posteroventral pallidotomy. Clin Neuropharmacol 21: 135-138

40. Merello M, Nouzeilles MI, Kuzis G et al. (1999) Unilateral radiofrequency lesion versus electrostimulation of posteroventral pallidum: a prospective randomized comparison. Mov Disord 14: (in press)
41. Meyer CHA (1997) Unilateral pallidotomy for Parkinson's disease promptly improves a wide range of voluntary activities especially gait and trunk movements. Acta Neurochir 68 (Suppl): 37-41

42. Ondo WG, Jankovic J, Lai EC et al. (1998) Assessment of motor function after stereotactic pallidotomy. Neurology 50: 266-270

43. Perrine K, Dogali M, Fazzini E et al. (1998) Cognitive functioning after pallidotomy for refractory Parkinson's disease. J Neurol Neurosurg Psychiatry 65: 150-154

44. Pfann KD, Penn RD, Shannon KM, Corcos DM (1998) Pallidotomy and bradykinesia Implications for basal ganglia function. Neurology 51: 796-803

45. Rilling LM, Filoteo JV, Roberts JW, Heilbrun MP (1996) Neuropsychological functioning in patients with Parkinson's disease pre- and post-pallidotomy. Arch Clin Neuropsych 11: 442

46. Riordan HJ, Flashman L, Carroll K, Roberts D (1997) Neuropsychological functioning before and after stereotactic ventroposterolateral pallidotomy in Parkinson's patients: Preliminary findings. Journal of the International Neuropsychological Society 3: 60 (Abstract)

47. Samuel M, Caputo E, Brooks DJ et al. (1998) A study of medial pallidotomy for Parkinson's disease: clinical outcome, MRI location and complications. Brain 121: 59-75

48. Samuel M, Ceballos-Baumann AO, Turjanski N et al. (1997) Pallidotomy in Parkinson's disease increases supplementary motor area and prefrontal activation during performance of volitional movements - An H215O PET study. Brain 120: 1301-1313

49. Schuurman PR, De Bie RMA, Speelman JD, Bosch DA (1997) Bilateral posteroventral pallidotomy in advanced Parkinson's disease in three patients. Mov Disord 12: 752-755

50. Scott R, Gregory R, Hines N et al. (1998) Neuropsychological, neurological and functional outcome following pallidotomy for Parkinson's disease - A consecutive series of eight simultaneous bilateral and twelve unilateral procedures. Brain 121: 659-675

51. Shannon KM, Penn RD, Kroin JS et al. (1998) Stereotactic pallidotomy for the treatment of Parkinson's disease - Efficacy and adverse effects at 6 months in 26 patients. Neurology 50: 434-438
52. Skalabrin EJ, Laws ER Jr, Bennett JP Jr (1998) Pallidotomy improves motor responses and widens the levodopa therapeutic window in Parkinson's disease. Mov Disord 13: 775-781

53. Soukup VM, Ingram F, Schiess MC et al. (1997) Cognitive sequelae of unilateral posteroventral pallidotomy. Arch Neurol 54: 947-950

54. Stebbins G, Gabrieli J, Goetz C, Shannon K, Penn R, Masciari F (1997) Impaired fronto-striatal memory functioning following pallidotomy in advanced Parkinson's disease. Neurology 48: A252 (Abstract)

55. Stebbins GT, Gabrieli JDE, Shannon KM, Penn RD, Goetz CG (1999) Impaired fronto-striatal cognitive functioning following posteroventral pallidotomy in advanced Parkinson's disease. Brain and Cognition (in press)

56. Sutton JP, Couldwell W, Lew MF et al. (1995) Ventroposterior medial pallidotomy in patients with advanced Parkinson's disease. Neurosurgery 36 : 1112-1117

57. Svennilson E, Torvik A, Lowe R, Leksell L (1960) Treatment of parkinsonism by stereotactic thermo lesions in the pallidal region. A clinical evaluation of 81 cases. Acta Psychiatr Neurol Scand 35: 358-377

58. Trépanier L, Saint-Cyr J, Lang A, Lozano A (1998) Hemisphere-specific cognitive and motor changes after unilateral posteroventral pallidotomy. Arch Neurol 55: 881-883

59. Trépanier LL, Saint-Cyr JA, Lozano AM, Lang AE (1998) Neuropsychological consequences of posteroventral pallidotomy for the treatment of Parkinson's disease. Neurology 51: 207-215

60. Tronnier VM, Fogel W, Kronenbuerger M, Steinvorth S (1997) Pallidal stimulation: an alternative to pallidotomy? J Neurosurg 87 : 700-705

61. Tsao KJ, Wilkinson S, Overman J et al. (1998) Pallidotomy lesion locations: Significance of microelectrode refinement. Neurosurgery 43: 506-512

62. Uitti RJ, Wharen RE, Turk MF et al. (1997) Unilateral pallidotomy for Parkinson's disease: Comparison of outcome in younger versus elderly patients. Neurology 49: 1072-1077 